Review Article

\title{
Genome-wide identification, classification and transcriptional analysis of nitrate and ammonium transporters in Coffea
}

Tiago Benedito dos Santos ${ }^{1,2}$, Joni Esrom Lima ${ }^{3,4}$, Mariane Silva Felicio ${ }^{1}$, João Danillo Moura Soares ${ }^{1}$ and Douglas Silva Domingues ${ }^{1,5}$

${ }^{1}$ Laboratório de Biotecnologia Vegetal, Instituto Agronômico do Paraná, Londrina, PR, Brazil.

${ }^{2}$ Programa de pós-graduação em Agronomia, Universidade do Oeste Paulista (UNOESTE), Presidente

Prudente, SP, Brazil.

${ }^{3}$ Departamento de Botânica, Instituto de Ciências Biológicas, Universidade Federal de Minas Gerais

(UFMG), Belo Horizonte, MG, Brazil.

${ }^{4}$ Centro de Energia Nuclear na Agricultura (CENA), Escola Superior de Agricultura "Luiz de Queiroz", (ESALQ), Universidade de São Paulo (USP), Piracicaba. SP, Brazil.

${ }^{5}$ Departamento de Botânica, Instituto de Biociências de Rio Claro, Universidade Estadual Paulista "Júlio Mesquita Filho" (UNESP), Rio Claro, SP, Brazil.

\begin{abstract}
Nitrogen $(\mathrm{N})$ is quantitatively the main nutrient required by coffee plants, with acquisition mainly by the roots and mostly exported to coffee beans. Nitrate $\left(\mathrm{NO}_{3}^{-}\right)$and ammonium $\left(\mathrm{NH}_{4}^{+}\right)$are the most important inorganic sources for $\mathrm{N}$ uptake. Several $\mathrm{N}$ transporters encoded by different gene families mediate the uptake of these compounds. They have an important role in source preference for $\mathrm{N}$ uptake in the root system. In this study, we performed a genome-wide analysis, including in silico expression and phylogenetic analyses of AMT1, AMT2, NRT1/PTR, and NRT2 transporters in the recently sequenced Coffea canephora genome. We analyzed the expression of six selected transporters in Coffea arabica roots submitted to $\mathrm{N}$ deficiency. $\mathrm{N}$ source preference was also analyzed in $C$. arabica using isotopes. C. canephora $\mathrm{N}$ transporters follow the patterns observed for most eudicots, where each member of the AMT and NRT families has a particular role in $\mathrm{N}$ mobilization, and where some of these are modulated by $\mathrm{N}$ deficiency. Despite the prevalence of putative nitrate transporters in the Coffea genome, ammonium was the preferential inorganic $\mathrm{N}$ source for $\mathrm{N}$-starved $\mathrm{C}$. arabica roots. This data provides an important basis for fundamental and applied studies to depict molecular mechanisms involved in $\mathrm{N}$ uptake in coffee trees.
\end{abstract}

Keywords: Coffee, nitrogen transport, nitrogen uptake, gene family evolution.

Received: March 03, 2016; Accepted: February 21, 2017.

\section{Introduction}

Nitrogen $(\mathrm{N})$ is one of the primary macronutrients and is a critical nutrient for plant growth and development (Konishi and Yanagisawa, 2014). $\mathrm{N}$ is imported into the roots through specific ion transporters in root cells from several sources. The main $\mathrm{N}$ inorganic forms absorbed by plants are ammonium $\left(\mathrm{NH}_{4}{ }^{+}\right)$and nitrate $\left(\mathrm{NO}_{3}{ }^{-}\right) \cdot \mathrm{NO}_{3}{ }^{-}$, due to nitrification reactions in the soil, is usually present in higher concentrations and is more mobile in soil when compared to $\mathrm{NH}_{4}^{+}$(Marschner, 2012; Luo et al., 2013). Nonetheless, both ions can be utilized by plants, $\mathrm{NH}_{4}{ }^{+}$and $\mathrm{NO}_{3}{ }^{-}$ have different energetic and biochemical characteristics for

Send correspondence to Douglas Silva Domingues. Departamento de Botânica, Instituto de Biociências de Rio Claro, Universidade Estadual Paulista (UNESP), Avenida 24-A 1515, 13506-900 Rio Claro, SP, Brazil. E-mail doug@rc.unesp.br assimilation, resulting in different net fluxes of both ions and $\mathrm{NH}_{4}^{+}-\mathrm{NO}_{3}^{-}$preference in plants (Patterson et al., 2010; Alber et al., 2012). These preferences are still poorly understood in tropical woody dicots.

Plants have evolved different transport systems that effectively adapt to changes of $\mathrm{N}$ availability in the environment. Ammonium and nitrate in plants have two uptake systems: a low-affinity transport system (LATS) operating in the millimolar concentration range and a saturable highaffinity transport system (HATS) operating at submillimolar concentrations (reviewed in Forde, 2000; Wang et al., 2012). Mainly LATS accomplish the $\mathrm{N}$ uptake at high external concentrations, while at concentrations below $0.5 \mathrm{mM} \mathrm{N}$, uptake is achieved through HATS.

Nitrate uptake by plant roots from soil solution is mediated by members of four gene families: NRT1/PTR (NPF, nitrate transporter 1/peptide transporter family), NRT2, 
CLC (chloride channels), and SLAC1/SLAH (slow anion channel-associated 1 homologues) (Dechorgnat et al., 2011; Wang et al., 2012; Léran et al., 2014). The largest families in Arabidopsis are NRT1 (involved in LATS) and NRT2 (involved in HATS), with 53 and 7 copies, respectively. Proteins of the AMT/Rh/Mep family (Ludewig et al., 2007) mediate ammonium transport across membranes. Both NRTs and AMTs are variable in their biochemical properties, tissue localization and transcriptional regulation.

AMT1s and AMT2s usually contain 11 putative transmembrane domains (Couturier et al., 2007; McDonald et al., 2012). The members of the AMT1 family are responsible for high affinity $\mathrm{NH}_{4}{ }^{+}$transport (von Wirén et al., 2000; Yuan et al., 2007), whereas at least some plant AMT2 members seem to transfer net $\mathrm{NH}_{3}$, yet no ionic currents across the membrane (Guether et al., 2009). The physiological roles of the $A M T 2$ proteins are less well understood than those of AMT1 proteins (Neuhäuser et al., 2009).

AMTs and NRTs have been characterized in several plant species and genera: Citrus (Camañes et al., 2009), Arabidopsis thaliana (Wang et al., 2012; Xu et al., 2012), Solanum lycopersicon (Graff et al., 2011), Medicago truncatula (Young et al., 2011; Pellizzaro et al., 2014), Cucumis sativus (Migocka et al., 2013), Zea mays (Sorgona et al., 2011), Sorghum bicolor (Koegel et al., 2013) and Puccinellia tenuiflora (Bu et al., 2013). However, there are no reports on the molecular mechanisms of $\mathrm{N}$ uptake in coffee, including preferential $\mathrm{N}$ source.

Coffee is one of the most traded commodities in the world, and Brazil has the largest production and is the second largest consumer of the beverage (Lashermes et al., 2008; Mondego et al., 2011). Fertilization practices are among the most important costs in coffee production (Fehr et al., 2012). The genus Coffea (Rubiaceae) has 124 species (Davis et al., 2011), with Coffea arabica and C. canephora being the two species of greatest economic importance (Vidal et al., 2010). C. arabica is an allotetraploid $(2 \mathrm{n}=4 \mathrm{x}$ $\left.=44-C^{a} C^{a} E^{a} E^{a}\right)$ and $C$. canephora is a diploid species $(2 \mathrm{n}$ $=2 \mathrm{x}=22-\mathrm{CC}$ ), allogamous and self-incompatible (Denoeud et al., 2014). C. arabica originated from a spontaneous hybridization between two diploid coffee species, C. canephora and C. eugenioides $(2 \mathrm{n}=2 \mathrm{x}=22$ - EE) (Vidal et al., 2010).

We present here a phylogenetic reconstruction of AMT1, AMT2, NRT1/PTR, and NRT2 gene families from the recently released Coffea canephora genome (Denoeud et al., 2014). These phylogenies are supplemented with transmembrane domain and subcellular localization predictions, and in silico expression profiling in C. canephora organs. We have also investigated the transcriptional responses of selected transporters under $\mathrm{N}$ starvation in $C$. arabica, as well as identified preferential $\mathrm{N}$ sources for uptake in C. arabica roots under $\mathrm{N}$ starvation. This study provides the basis to develop future in-depth physiological and molecular studies to fully address $\mathrm{N}$ utilization in plants of the Coffea genus, and opens a perspective on the understanding of modules that control $\mathrm{NH}_{4}{ }^{+}$and $\mathrm{NO}_{3}{ }^{-}$homeostasis in coffee roots, which are important targets for breeding and biotechnology.

\section{Material and Methods}

\section{Identification and phylogenetic analysis of NRT and AMT gene families in coffee}

Basic procedures of annotation followed a report on the evolution of nitrate and ammonium transporters (von Wittgenstein et al., 2014). Protein sequences of AMTs and NRTs annotated in Arabidopsis thaliana, Medicago truncatula, Populus trichocarpa and Vitis vinifera by von Wittgenstein et al. (2014) were used as queries for BLASTP searches against the $C$. canephora genome (http://coffee-genome.org/).

The parameters BLASTP used were also based on von Wittgenstein et al. (2014), with an expected threshold lower than 1 e- 50 and at least $30 \%$ of identity. Transmembrane (TM) domains were predicted using TMHMM v2 software (Krogh et al., 2001). Sequences with at least 8 TM domains were compared with the reference sequences, and only the ones that had a maximum difference of 50 amino acids in length were selected for further analyses. Subcellular localization was predicted using MultiLoc2 (Blum et al., 2009), with the MultiLoc2-HighRes (Plant), 10 Locations algorithm. For phylogenetic analyses, we included Oryza sativa, Zea mays, Sorghum bicolor and Brachypodium distachyon protein sequences for each transporter family. Sequences were aligned using MUSCLE (Edgar, 2004). This alignment was used to generate neighbor-joining trees (Saitou and Nei, 1987) based on distance matrices using the Jones-Taylor-Thornton model and pairwise deletion. The resampling method was bootstrapping and consisted of 1,000 replicates. All procedures were run using MEGA6 software (Tamura et al., 2013). Phylogenies were rooted using Arabidopsis sequences belonging to another family as outgroup.

\section{Transcriptional profile of $\mathrm{N}$ transporters in $C$. canephora}

For in silico expression profiling, RNAseq data from different organs and tissues of C. canephora were obtained from the "RNA-seq RPKM" track available on JBrowser at the Coffee Genome Hub database (http://coffee-genome.org/; Dereeper et al., 2015). This data was compiled to a spreadsheet to generate heatmaps that use a color coding to differentiate expression levels. The expression unit used was reads per kilobase per million reads (RPKM). The software Bio-Analytic Resource for Plant Biology (BAR) HeatMapper Plus (http://bar.utoronto.ca/) was used to generate the heatmaps of AMTs and NRTs genes. 
Transcriptional profile of $\mathrm{N}$ transporters in $C$. arabica roots - $\mathrm{N}$ starvation experiment

We evaluated the transcriptional profile of 3 AMT and 3 NRT transporters in C. arabica roots submitted to N starvation (Table 1), which had homologs in ESTs of the Brazilian Coffee Genome Consortium database (Mondego et al., 2011). Basic procedures of $\mathrm{N}$ starvation experiment are summarized in Figure S1 (Supplementary material). Overall procedures and plant nutritive solution are detailed in de Carvalho et al. (2013). After 4 weeks on hydroponic devices for acclimation, $C$. arabica L. cv. IAPAR59 5month old plants were harvested for time point 0 and then transferred to a modified $\mathrm{N}$-free solution, where lateral roots were harvested at 1 day and 10 days after transfer into the $\mathrm{N}$-free solution. Experiments were conducted twice, with a minimum of three biological replicates per experiment. All samples were harvested between 09:30 am and 10:30 am. Biological replicates were represented by pools of coffee lateral roots of at least nine plants each, at the same developmental stage. After harvesting, all samples were frozen immediately in liquid nitrogen and stored at $-80{ }^{\circ} \mathrm{C}$ until RNA extraction.

\section{RNA isolation, cDNA synthesis and semi-quantitative RT-PCR}

Total RNA from C. arabica L. cv. IAPAR59 roots was isolated following the same procedures used by previous studies of our group (dos Santos et al., 2011). We treated RNA samples with DNase to remove traces of DNA contamination, and after dissolved in RNase-free water, the RNA concentration was determined using a NanoDrop ${ }^{\circledR}$ ND-100 spectrophotometer (Waltham, MA, USA). Complementary DNA (cDNA) was synthesized in a final volume of $20 \mu \mathrm{L}$ using $5 \mu \mathrm{g}$ of total RNA by using SuperScript ${ }^{\circledR}$ III Reverse Transcriptase (Invitrogen), following the manufacturer's instructions

Primers (Table 1) were designed using Primer Express (version 3.0) according to parameters established by the software to obtain amplicons of 100 base pairs with a Tm of $60^{\circ} \mathrm{C} \pm 1{ }^{\circ} \mathrm{C}$ (Table 1). Amplification was performed according to the following temperature profile: 2 min initial denaturation at $94{ }^{\circ} \mathrm{C} ; 30$ cycles of $94^{\circ} \mathrm{C}$ for $1 \mathrm{~min}, 60^{\circ} \mathrm{C}$ for $1 \mathrm{~min}, 72^{\circ} \mathrm{C}$ for $1 \mathrm{~min}$; end extension of $3 \mathrm{~min}$ at $72^{\circ} \mathrm{C}$; final hold at $4{ }^{\circ} \mathrm{C}$. Cycles for RT-PCR analysis were based on Brandalise et al. (2009). Amplicons were verified in 2\% agarose gel electrophoresis with sodium boric acid (SB) buffer ( $0.5 \mathrm{M} \mathrm{NaOH}, \mathrm{pH}$ adjusted to 8.5 with boric acid), stained with ethidium bromide and photographed. The captured images were processed for densitometric analysis using the Image $1.43 \mathrm{U}$ software, as previously described by Freschi et al. (2009) and dos Santos et al. (2015). Transcriptional profiles were normalized using EFl $\alpha$, a reference gene recommended by de Carvalho et al. (2013) for this condition. Semi-quantitative RT-PCR analysis was repeated at least three times for each sample.

\section{Measurement of ${ }^{15} \mathrm{~N}$ influx in coffee roots}

Coffea arabica L. cv. IAPAR59 seedlings were hydroponically grown under non-sterile conditions in a greenhouse according to the following regime: $14 / 10 \mathrm{~h}$ light/dark and temperature $28^{\circ} \mathrm{C} / 18^{\circ} \mathrm{C}$. Plants were grown in nutrient solution containing $1 \mathrm{mM} \mathrm{KH}_{2} \mathrm{PO}_{4}, 1 \mathrm{mM} \mathrm{MgSO}_{4}, 250 \mu \mathrm{M}$ $\mathrm{K}_{2} \mathrm{SO}_{4}, 250 \mu \mathrm{M} \mathrm{CaCl}_{2}, 100 \mu \mathrm{M} \mathrm{Na}-\mathrm{Fe}-E D T A, 50 \mu \mathrm{M} \mathrm{KCl}$, $50 \mu \mathrm{M} \mathrm{H}_{3} \mathrm{BO}_{3}, 5 \mu \mathrm{M} \mathrm{MnSO}_{4}, 1 \mu \mathrm{M} \mathrm{ZnSO}, 1 \mu \mathrm{M} \mathrm{CuSO}_{4}$, and $1 \mu \mathrm{M}$ NaMoO 4 (pH adjusted by 2 mM MES, pH 5.8, Sigma-Aldrich). The nutrient solution was replaced every two days during the first week. After the acclimation period, the plants were submitted to $\mathrm{N}$ sufficient $(+\mathrm{N}, 2 \mathrm{mM}$ $\mathrm{NH}_{4} \mathrm{NO}_{3}$ ) or $\mathrm{N}$ starvation (-N, without $\mathrm{N}$ supply) nutrient solution for three days. Influx measurements of ${ }^{15} \mathrm{~N}$-isotope in plant roots were conducted after rinsing the roots in $1 \mathrm{mM} \mathrm{CaSO}_{4}$ solution for $1 \mathrm{~min}$, followed by an incubation for $10 \mathrm{~min}$ in nutrient solution containing $0.2 \mathrm{mM}$ or $2 \mathrm{mM}$ of ${ }^{15} \mathrm{~N}$-isotope with the equimolar concentration containing either ${ }^{15} \mathrm{NH}_{4} \mathrm{NO}_{3}\left(42.52\right.$ atom $\left.\%{ }^{15} \mathrm{~N}\right)$ or $\mathrm{NH}_{4}{ }^{15} \mathrm{NO}_{3}(41.62$ atom $\%{ }^{15} \mathrm{~N}$ ) as a sole $\mathrm{N}$ source, and finally washed in $1 \mathrm{mM}$ $\mathrm{CaSO}_{4}$ solution. Roots were harvested and stored at $-70{ }^{\circ} \mathrm{C}$ before milled. Each sample was ground in liquid $\mathrm{N}_{2}$ and dried at $55{ }^{\circ} \mathrm{C}$ for five days. The ${ }^{15} \mathrm{~N}$ and $\% \mathrm{~N}$ determination was performed by isotope ratio mass spectrometry (ANCA SL da Sercon, England) with $5 \mathrm{mg}$ of dried samples.

Table 1 - Coffea arabica transcriptional analysis: RT-PCR primers and orthologs in Arabidopsis and C. canephora genomes.

\begin{tabular}{lllllcr}
\hline \multirow{2}{*}{ Gene } & Forward Primer & Reverse Primer & NCBI Accession & $\begin{array}{c}\text { Arabidopsis } \\
\text { thaliana }\end{array}$ \\
\hline CaAMTa & AGCCGAATACATCTGCAACC & GAAGGTATGTGGTGTCGATGG & GW473095 & AT4G13510 & Cc03_g06810 \\
CaAMTb & CATTCCTTCGGGCTCTTACA & GCAATGGAGCCACTGGTTAT & GW483639 & AT4G13510 & Cc01_g14140 \\
CaAMTc & TGCGTGCATTGTATCTTCTGA & GCAGTCCATGGAGAAGAAGC & GT683246 & AT2G38290 & Cc07_g19360 \\
CaNRTa & TATGCCTTGGTGTCATTGGA & CTGCTGCAGACACCTTGAAA & GW479551 & AT1G69850 & Cc02_g36020 \\
CaNRTb & CTCGGAGAGAAAGATGAGCAG & GGACCCAACCACCAGTTTA & GW442751 & AT2G26690 & Cc06_g08580 \\
CaNRTc & GCTGCTGCTGTGGAAGAAGT & CCAAGCTTCTCAAAGGTCTCA & GT693501 & AT5G62680 & Cc04_g15770 \\
\hline
\end{tabular}




\section{Statistical Analysis}

Statistical analyses was done by one-way ANOVA using Sisvar software (Ferreira, 2011), followed by Tukey's multiple comparison tests ( $\mathrm{p}<0.05$ level).

\section{Results and Discussion}

\section{Genome-wide analysis of ammonium transporters in C. canephora genome}

All $\mathrm{N}$ transporter families in C. canephora had a copy number under the range found for most eudicots (von Wittgenstein et al., 2014; Pii et al., 2014; Table 2). We identified eight copies of ammonium transporter genes, four belonging to the AMT1 family and the others to AMT2. Three members of super-group A compose the $C$. canephora AMT1 family, and one member belongs to B super-group (Figure 1), which is highly contrastant to Populus, a tree that contains an expanded family of ammonium transporters (Couturier et al., 2007; von Wittgenstein et al., 2014). The presence of only one member in the coffee tree genome suggests that genome duplication mechanisms were not relevant to $A M T 1$ evolution in coffee trees.

The $A M T 1$ gene family comprises four members with 9-11 predicted TM domains. Almost all AMT1 transporters were predicted to be located in the endoplasmic reticulum, and only one AMT1 (Cc03_g06810) has been indicated with subcellular localization in the Golgi apparatus. Members of AMT2 family have 11 TM domains and only one (Cc07_g11400, sub-group B-II-E) was localized on the Golgi apparatus. Other C. canephora AMT2 members (sub-group A-II-E and B-I-E) are located in the endoplasmic reticulum. Interestingly, we did not find any $A M T 2$ transporter in C. canephora from super-group A-I, the sole group with biochemically characterized members (von Wittgenstein et al., 2014). Detailed information on TM prediction and subcellular localization are available in Tables $\mathrm{S} 1$ and $\mathrm{S} 2$.

Table 2 - Comparison of members from the $A M T 1, A M T 2, N R T 1 / \mathrm{PTR}$ and NRT2 gene families in Viridiplantae, based in von Wittgenstein et al. (2014) and Pii et al. (2014).

\begin{tabular}{lcccc}
\hline & \multicolumn{4}{c}{ Number of members } \\
\cline { 2 - 5 } Species & AMT1 & AMT2 & NRT1/PTR & NRT2 \\
\hline Arabidopsis thaliana & 5 & 1 & 51 & 6 \\
Coffea canephora & 4 & 4 & 57 & 3 \\
Glycine max & 5 & 5 & 96 & 3 \\
Oryza sativa & 2 & 6 & 65 & 3 \\
Physcomitrella patens & 5 & 10 & 18 & 8 \\
Populus trichocarpa & 6 & 5 & 70 & 7 \\
Selaginella moellendorfii & 1 & 0 & 31 & 2 \\
Setaria italica & 2 & 6 & 74 & 7 \\
Vitis vinifera & 1 & 1 & 44 & 4 \\
\hline
\end{tabular}

In silico expression analysis of putative $C$. canephora $A M T 1$ genes (Figure 3A) showed $C c 01 \_g 14140$ as the lowest expressed $A M T 1$ gene. Two genes $\left(C c 01 \_g 17670\right.$ and Cc09_g03020) were preferentially transcribed in roots, whereas Cc03_g06810 had higher expression in aboveground organs. $C c 01$ g17670 is the ortholog of the AtAMT1;4 gene (At4g28700), with $75 \%$ of identity. Both genes belong to group A-I E (Figure 1). AtAMT1;4 is a pollen high-affinity ammonium transporter; the overexpression of this gene in roots of mutant plants demonstrated that this gene is able to mediate ammonium uptake into $A$. thaliana roots (Yuan et al., 2009). Thus, probably Cc01_g17670 is also a high-affinity ammonium transporter, but not specific to pollen as AtAMT1;4, due to the low expression in stamina ( $0,1 \mathrm{RPKM})$.

Cc03_g06810, the ortholog of the AtAMT1;1 gene of A. thaliana (At4g13510), was the only gene expressed in all tissues, with higher expression in perisperm, indicating that ammonium transport may have some impact in fruit development. Compared to other Arabidopsis AMT1 genes, AtAMT1; 1 is expressed more broadly, including roots, sepals, and leaves (von Wittgenstein et al., 2014), which may also explain the expression of $C c 03 \_g 06810$ in all $C$. canephora tissues.

Considering a RPKM $>1$, two members of the AMT2 family had expression in roots and two in aerial parts (Table S2). Cc07 g19360 was the highest expressed AMT2 gene, with prevalence in roots (Figure 3B). The closest homolog in Populus, POPTR_0001s31280, (Figure 2) has a proeminent expression in reproductive tissues (von Wittgenstein et al., 2014), a pattern that is not observed in coffee.

\section{Nitrate transporters in the $C$. canephora genome}

The NRT1/PTR and NRT2 families were represented by 57 and three copies, respectively, in the $C$. canephora genome (Table 2). The C. canephora NRT1/PTR family is similar to the average for land plants, which has 54 family members (von Wittgenstein et al., 2014). Most of them were predicted as cytoplasmatic (25) or located in the plasma membrane (15) (Table S3). Other genes were located in Golgi apparatus (12), peroxisome (3), endoplasmic reticulum (Cc01_g06540) and extracellular regions $(\mathrm{CcO} g 31780)$. The members of this family possess from 8-12 predicted TM domains. All 10 NRT1 superfamilies are represented in C. canephora (Figure S2). Considering an RPKM $>1,12 \mathrm{NRTl} / \mathrm{PTR}$ members were expressed in all tissues and three genes (Cc01_g11750, Cc04_g15710, Cc01_g05330) were exclusively expressed in roots (Figure 4, Table S3).

Cc08_g12800, although expressed in aboveground organs, was the transcriptionally most active NRT transporter in roots (Figure 4, Table S3). The Arabidopsis ortholog of this gene is AtNRT1; 1 (Atlg12110); both genes are in 


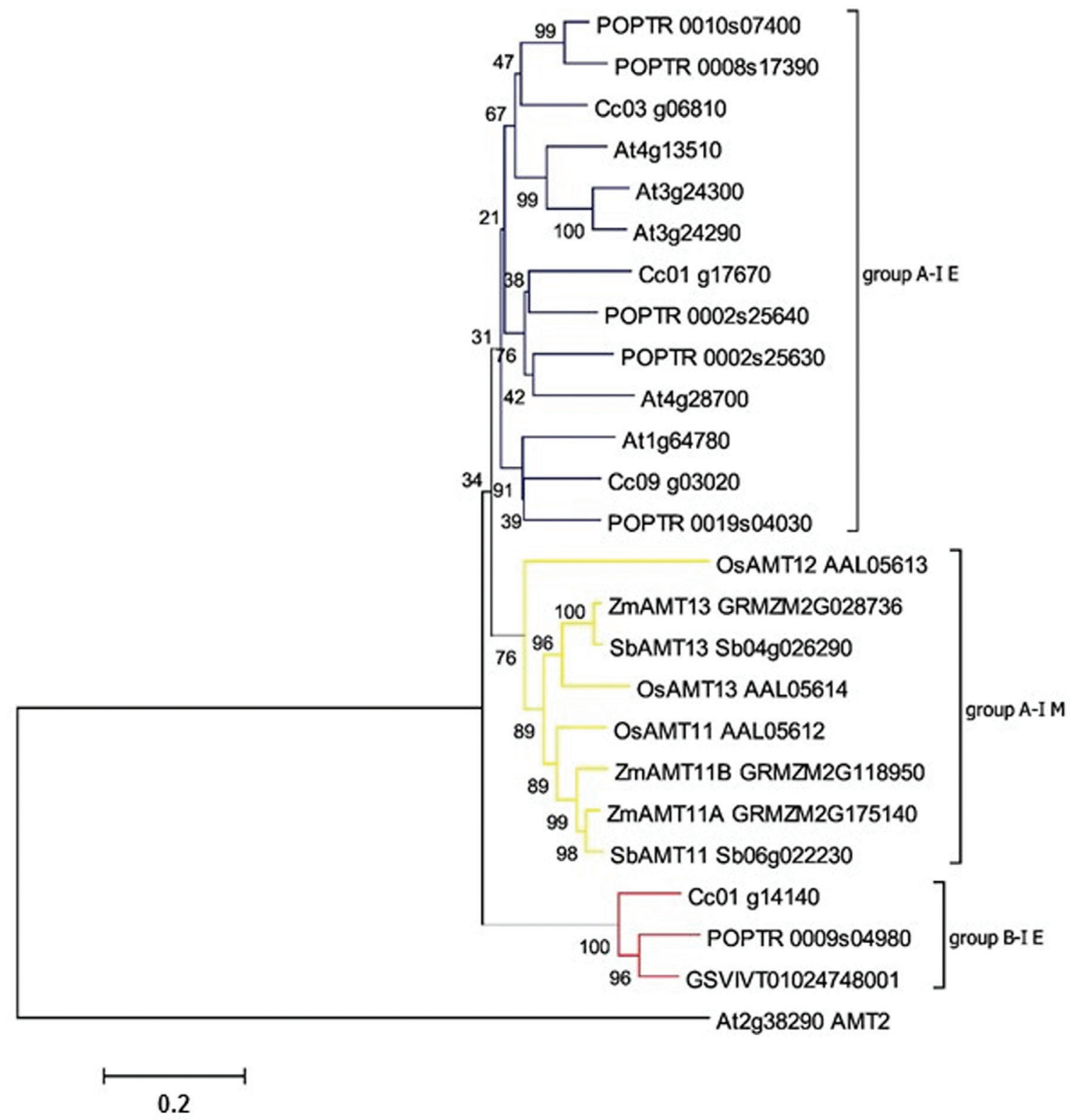

Figure 1 - Neighbor joining phylogenetic analysis of the $A M T 1$ family. The tree was rooted using an $A$. thaliana AMT2 gene as an outgroup. Percent bootstrap values from 1,000 replicates are given. All C. canephora genes are placed in clades with $>50 \%$ of bootstrap support. Taxonomic groups are colored based on groups: blue refers to group A eudicot sequences; yellow represents monocot sequences in group A, and red illustrates dicot sequences in group B. Accession numbers are shown. Codes were retrieved from the Coffee Genome Hub for C. canephora and Phytozome for all other species. Phylogenetic groups were based in von Wittgenstein et al. (2014).

super-group B, group I E (Figure S2). AtNRT1;1 is highly expressed in roots, and is described as a dual transporter that acts in high and low-affinity nitrate uptake, mediated by phosphorylation (Liu and Tsay, 2003). Phylogenetic relations and expression profiles indicate that Cc08_g12800 probably has the same function as AtNRT1;1.

We observed that the gene Cc11_g13590 is the most expressed in aboveground organs (Table S3). This gene is in the super-group D, group IV E with the ortholog AtNRT1;7 (At1g69860) (Figure S2), that is expressed in phloem of older leaves, more specifically restricted to the sieve element and companion cell complex (Fan et al., 2009). Therefore, the probable function of this gene is to transport nitrate from older leaves to tissues demanding $\mathrm{N}$ (Fan et al., 2009). If the Cc11_gl3590 gene shares the same function of its ortholog, this may be the reason for the higher expression of this gene in several tissues. In pistils, the most expressed gene of $N R T 1 /$ PTR family was Cc04_g15770, whose ortholog in the Arabidopsis genome is AtNPF2.11 (At5g62680), also named as AtGTR2. This 


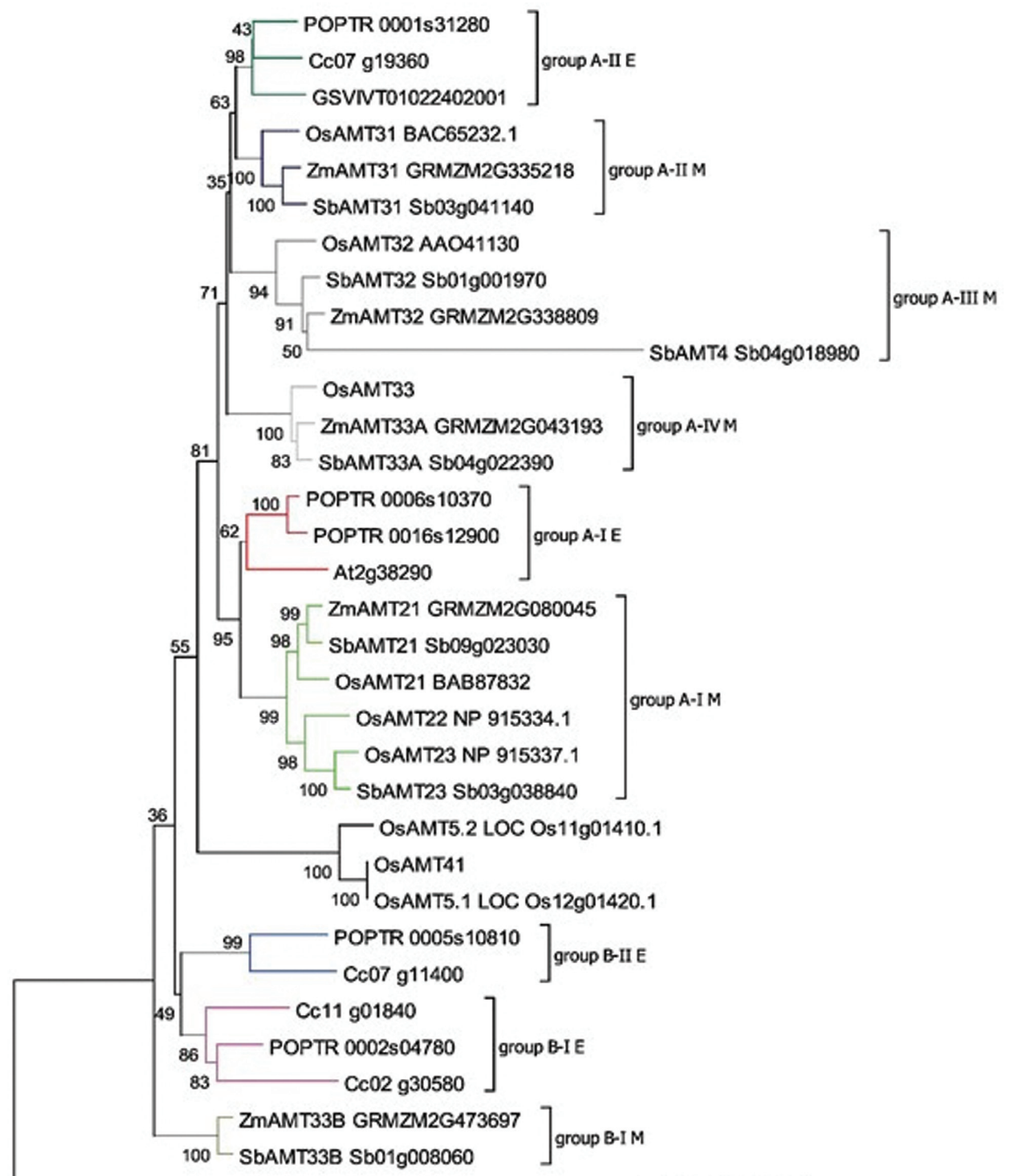

At4g13510 AMT1

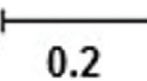

Figure 2 - Neighbor joining phylogenetic analysis of the $A M T 2$ family. The tree was rooted using an $A$. thaliana AMT1 gene as an outgroup. Percent bootstrap values from 1,000 replicates are given. All C. canephora genes are placed in clades with $>50 \%$ of bootstrap support. Taxonomic groups are colored based on groups: dark green and red refer to group A eudicot sequences; dark blue, dark grey, light grey and light green represent monocot sequences in group A-II; blue and purple illustrate dicot sequences in group B, grey represents group B monocot sequences. Accession numbers are shown. Codes were retrieved from the Coffee Genome Hub for C. canephora sequences and Phytozome for all other species. Phylogenetic groups were based in von Wittgenstein et al. (2014). 


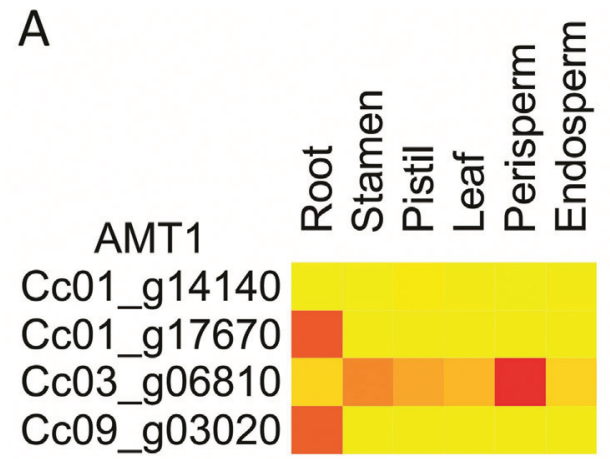

$0153045607590105120135>150$

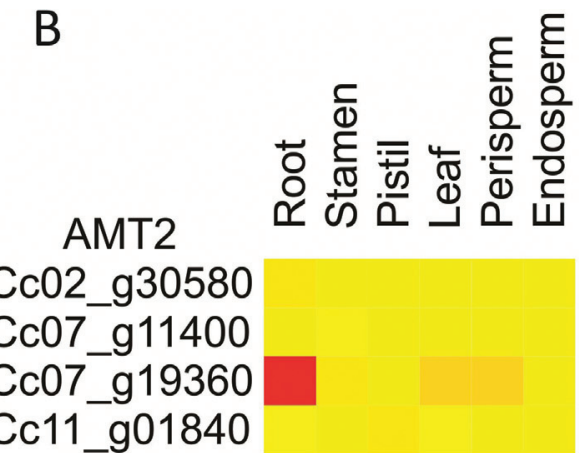

$\begin{array}{lllllllllll}0 & 2 & 4 & 6 & 8 & 10 & 12 & 14 & 16 & 18 & >20\end{array}$

Expression levels (RPKM)

Expression levels (RPKM)

Figure 3 - In silico expression profile of C. canephora AMT1 (A) and $A M T 2$ (B) gene families. RNAseq data from roots, stamen, pistil, leaves, perisperm, and endosperm were obtained from Coffee Genome Hub database.

gene acts as a transporter for glucosinolates, suggesting that it possibly evolved through neo-functionalization of NRT1/PTR family members (Nour-Eldin et al., 2012). AtNPF2.11 has its higher transcription in petals, sepals, and stamina (von Wittgenstein et al., 2014). Since Cc04_g15770 had almost no expression in stamina, more studies are necessary to characterize the role of that $C$. canephora gene in reproductive tissues. In the seed and perisperm, the gene that had higher transcriptional values was $C c 02 \_g 05650$, in agreement with the high expression profile of its ortholog oligopeptide transporter At $2 \mathrm{~g} 40460$ in Arabidopsis seeds (von Wittgenstein et al., 2014). These two genes are part of the super-group I, group I E (Figure S2).

The NRT2 family comprises three members (Figure 5) that were predicted with $11 \mathrm{TM}$ domains, two of them predicted to be localized in peroxisome, whereas the other one ( $\left.C c 01 \_g 10620\right)$ was predicted to be in cytoplasm. The $N R T 2$ gene family had two genes exclusively expressed in roots, considering RPKM $>1$ (Table S4), where the most active was $C c 01$ g10640. The gene with higher expression in the aerial parts $(C c 11, g 15480)$ was also the less expressed in roots (Figure 6; Table S4).

AtNRT2;1 (At1g08090) shares higher identity with Cc01_g10640 than the other Arabidopsis NRT2 genes in group I E (Figure 5). AtNRT2;1 is the major inducible high-affinity transporter of nitrate (iHATS). When this gene was disrupted in Arabidopsis, $72 \%$ of the iHATS was reduced ( $\mathrm{Li}$ et al., 2007). The transcriptional profile of Cc01_g10640 suggests that this gene probably acts in the same function as AtNRT2;1. AtNRT2;1 is targeted to the root plasma membrane (Chopin et al., 2007), but the predicted localization of Cc01_g10640 is in peroxisomes. According to von Wittgenstein et al. (2014), the high degree of peroxisome localization for NRT2 is unexpected, and it may be due to difficulties predicting hydrophobic, mem- brane bound proteins, added to inaccuracy in recentlyreleased genome annotations.

The gene Cc11_g15480, that has been shown more expressed in aerial parts is related to AtNRT2;5 (At 1 12940), and these genes are in group II E. AtNRT2;5 is highly expressed in senescing leaves, and is described as being a nitrate repressible gene, having maximum expression in the absence of nitrate (Okamoto et al., 2003).

\section{Transcriptional responses of $\mathrm{N}$ transporters in C. arabica roots}

We analyzed the transcriptional profile of three AMT and three NRT transporters in C. arabica in response to N depletion. Orthologs of these genes in C. canephora genome are indicated in Table 1 and Supplementary Tables $\mathrm{S} 1$ to S3. Since transcriptional changes related to the lack of $\mathrm{N}$ sources can also be species-specific, it is important to highlight that further work should address if the same transcriptional pattern is observed in C. canephora; but, to our knowledge, this is the first study that evaluates the transcriptional profile of $\mathrm{N}$ transporters in coffee tree roots.

CaAMTa and CaAMTb were induced by $\mathrm{N}$ starvation (Figure 7A and B). CaAMTb is an AMT1 transporter with low expression in roots of $C$. canephora (Figure 3, Table $\mathrm{S} 1$ ), which is in agreement with RT-PCR analysis, where this gene was the lesser expressed among the ammonium transporters under $\mathrm{N}$-sufficient conditions. Under $\mathrm{N}$ suppression, CaAMTb was the most induced gene, suggesting its participation in ammonium uptake in N-deficiency conditions and warranting further studies in functional analyses to depict its transport capacity.

Nitrate transporters displayed distinct transcriptional patterns (Figure 8): CaNRTa and CaNRTc showed an increasing gradient of transcripts, suggesting a direct role in molecular responses to $\mathrm{N}$ starvation, while $\mathrm{CaNRTb}$ was down-regulated by short-term $\mathrm{N}$-starvation and induced in long-term N-starvation. 


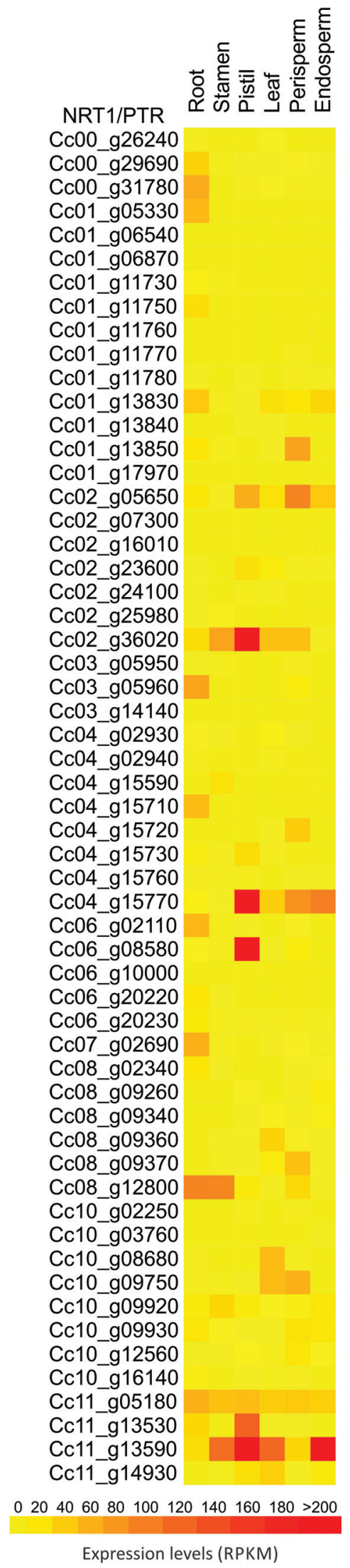

Figure 4 - In silico expression profile of $C$. canephora NRT1/PTR gene family. RNAseq data from roots, stamen, pistil, leaves, perisperm, and endosperm were obtained from Coffee Genome Hub database.
The gene with most prominent changes in transcriptional values under $\mathrm{N}$ depletion was CaNRTa. Its ortho$\log$ in C. canephora, Cc02 g36020, is expressed in several tissues, with prevalence in pistil. Kanno et al. (2012) demonstrated that the Arabidopsis ortholog of this N transporter (Table 1, Figure S2) is also involved in abscisic acid transport, suggesting that this transporter may have role in several abiotic stress responses.

\section{Uptake of ammonium exceeds nitrate in $C$. arabica roots}

To determine the preferential inorganic $\mathrm{N}$ source of coffee roots, plants were acclimated in nutrient solution under N-sufficient or N-deficient conditions and short-term ${ }^{15} \mathrm{~N}$-labeled influxes with equimolar concentrations of ${ }^{15} \mathrm{NH}_{4} \mathrm{NO}_{3}$ or $\mathrm{NH}_{4}{ }^{15} \mathrm{NO}_{3}$ were measured. For HATS activity, $\operatorname{root}{ }^{15} \mathrm{~N}$-label was measured at $0.2 \mathrm{mM}$, and the LATS activity was estimated for $2 \mathrm{mM}$ of external ${ }^{15} \mathrm{NH}_{4}^{+}$or ${ }^{15} \mathrm{NO}_{3}{ }^{-}$concentrations. At sufficient $\mathrm{N}$ supply, ${ }^{15} \mathrm{NH}_{4}^{+}$uptake measured at high-affinity concentration rates exceeded that of ${ }^{15} \mathrm{NO}_{3}{ }^{-}$by 2.3 -fold (Figure 9A), while in $\mathrm{N}$-deficient plants, the ammonium influxes were 3.5 -fold higher compared to nitrate uptake (Figure 9A). LATS activity became apparent at higher external $\mathrm{N}$ concentration, $2 \mathrm{mM}$ ${ }^{15} \mathrm{NH}_{4} \mathrm{NO}_{3}$ or $\mathrm{NH}_{4}{ }^{15} \mathrm{NO}_{3}$, where ${ }^{15} \mathrm{NH}_{4}{ }^{+}$influxes were 2.3fold increased under $\mathrm{N}$ sufficient and 1.6-fold higher for $\mathrm{N}$ deficient roots in comparison to low external $\mathrm{N}$ supply (Figure 9A and B). By contrast, the $\mathrm{NO}_{3}{ }^{-}$LATS displayed less activity, since only 1.7 -fold and 1.5 -fold higher ${ }^{15} \mathrm{NO}_{3}{ }^{-}$ influxes were observed under ample and limited $\mathrm{N}$ supply, respectively (Figure 9B), when compared to HATS. In addition, at low affinity external concentrations, ${ }^{15} \mathrm{NH}_{4}{ }^{+}$influxes were 3.5 times higher than those of ${ }^{15} \mathrm{NO}_{3}^{-}$, independent of the $\mathrm{N}$ nutritional status of the plants (Figure 9B). Taken together, these results demonstrate that high and low-affinity transport systems in coffee roots are active for both inorganic $\mathrm{N}$ forms, and that under low external $\mathrm{N}$ availability, the preference for ammonium uptake over nitrate indicates that the HATS is differentially regulated. Evidence for this come from the ${ }^{15} \mathrm{~N}$-labeled influxes in contrasting $\mathrm{N}$ supply growth conditions, in which $\mathrm{N}$ deficiency for three days caused an induction of 1.3-fold of HATS activity for ammonium influxes but not for nitrate uptake rates (Figure 9A). Conversely, regulation of LATS activity was absent irrespective of $\mathrm{N}$ form or plant $\mathrm{N}$ status (Figure 9B).

Physiological studies have demonstrated the presence of two high affinity transport systems for nitrate and one for ammonium in higher plants (Crawford and Glass, 1998; Loqué and von Wirén, 2004). Influx measurements in roots of several species revealed that a low capacity, constitutive active transport system is responsible for acquisition of nitrate and ammonium from low external $\mathrm{N}$ concentrations, and the extent of this absorption is variable among different 


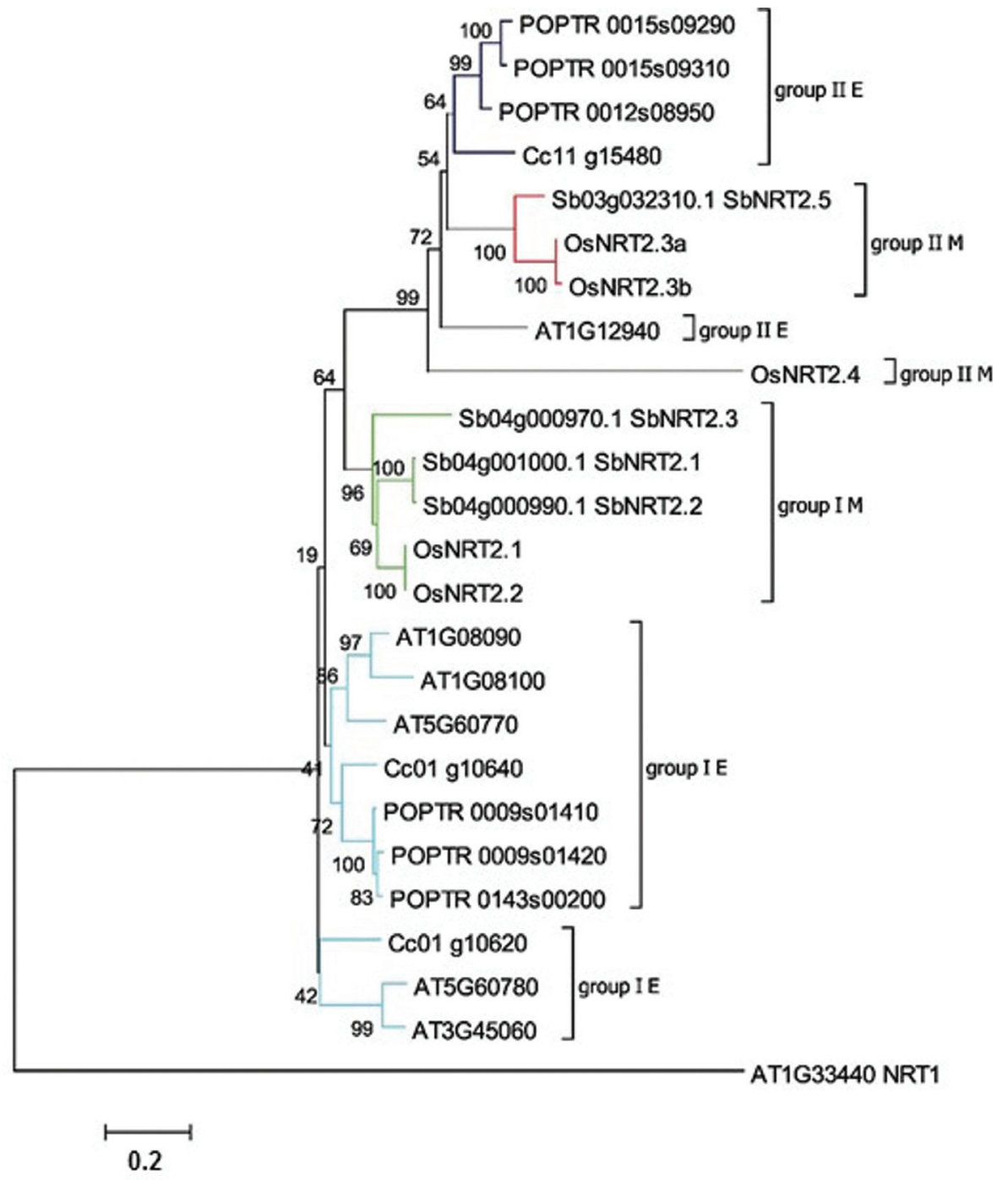

Figure 5 - Neighbor joining phylogenetic analysis of the NRT2 family. The tree was rooted using an A. thaliana NRT1 gene as an outgroup. Percent bootstrap values from 1,000 replicates are given. Taxonomic groups are colored based on groups: light blue to group I eudicot sequences; green represent monocot sequences in group I; dark blue and grey illustrate dicot sequences in group II; red and grey represent group B monocot sequences. Accession numbers are shown. Codes were retrieved from the Coffee Genome Hub for C. canephora and Phytozome for all other species. Phylogenetic groups were based in von Wittgenstein et al. (2014).

NRT2

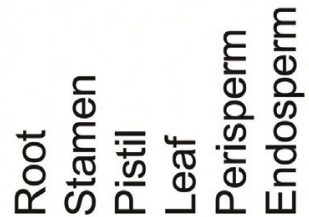

Cc01_g10620
Cc01_g10640
Cc11_g15480

$\begin{array}{lllllllllll}0 & 12 & 24 & 36 & 48 & 60 & 72 & 84 & 96 & 108 & >120\end{array}$

Expression levels (RPKM)

Figure 6 - In silico expression profile of C. canephora NRT2 gene family. RNAseq data from roots, stamen, pistil, leaves, perisperm, and endosperm were obtained from Coffee Genome Hub database. species (Siddiqi et al., 1989; Serna et al., 1992; Wang et al., 1993; Kronzucker et al., 1997, 1998; Näsholm et al., 1998; Rawat et al., 1999; Zhuo et al., 1999; von Wirén et al., 2000; Tischner, 2000). Furthermore, for both $\mathrm{N}$ forms, an inducible high affinity transport system (iHATS) occurs in plants, in which HATS activity is transiently activated under $\mathrm{N}$ limited growth conditions and is repressed by high external N supply (Rawat et al., 1999; von Wirén et al., 2000; Nazoa et al., 2003; Orsel et al., 2006; Loqué et al., 2006). In addition, a key feature of the nitrate iHATS activity is that it can be rapidly induced in the presence of nitrate (Aslam et al., 1996; Kronzucker et al., 1999) although it seems to be less effective for ammonium (Loqué and von Wirén, 2004; Loqué et al., 2007; Lanquar et al., 2009).

The lack of activation of nitrate uptake by $\mathrm{N}$ deficient coffee roots might indicate that ammonium either causes a 

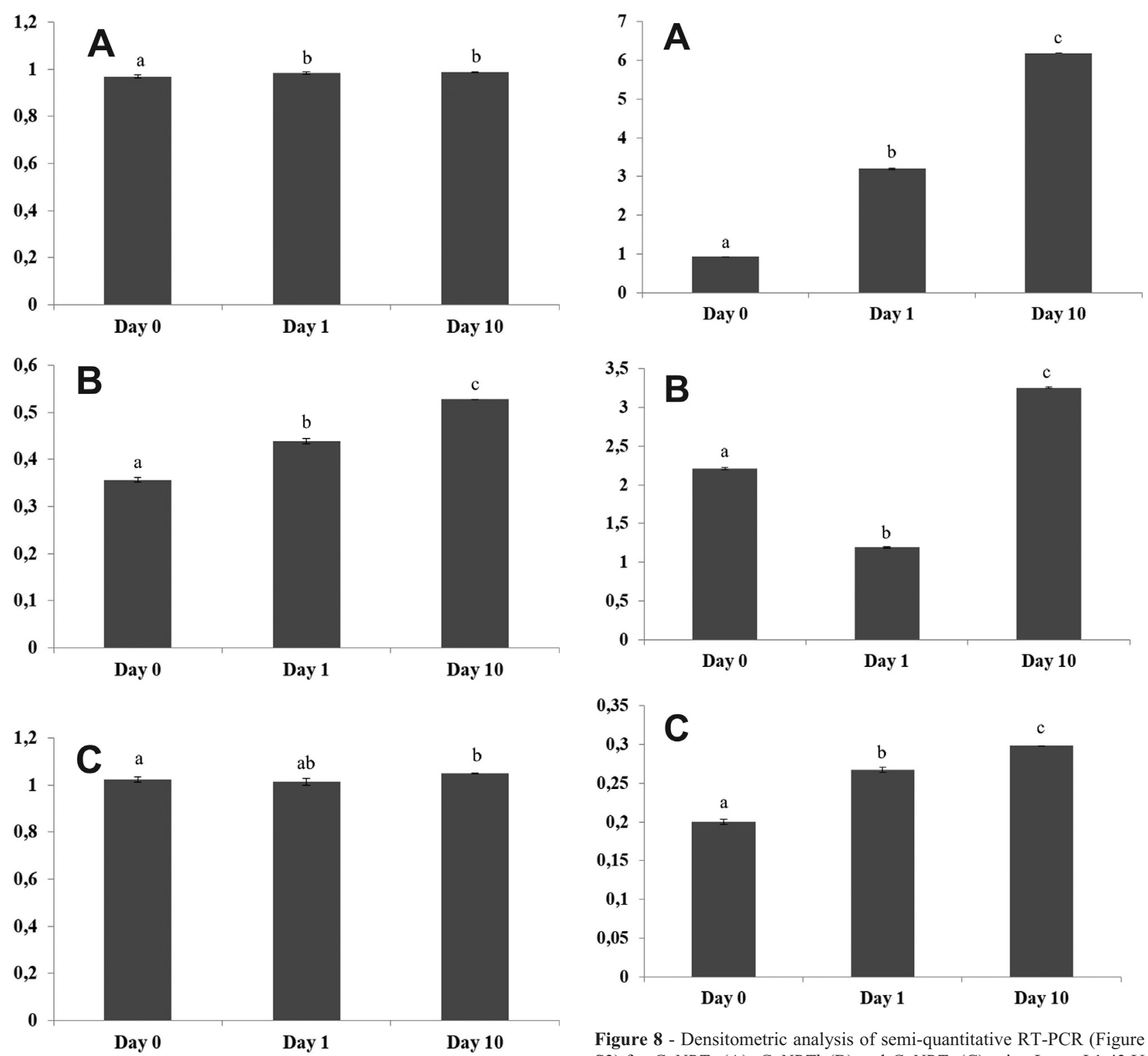

Figure 8 - Densitometric analysis of semi-quantitative RT-PCR (Figure S3) for CaNRTa (A), CaNRTb (B) and CaNRTc (C) using ImageJ $1.43 \mathrm{U}$ software. $E F 1 \alpha$ gene was used as an internal control to normalize the expression level. The data represent the mean \pm standard deviation of three biological replicates. Letters indicate significant differences between genotypes in each treatment by Tukey test $(\mathrm{p}<0,05)$. S3) for CaAMTa (A), CaAMTb (B) and CaAMTc (C) using ImageJ $1.43 \mathrm{U}$ software. $E F l \alpha$ gene was used as an internal control to normalize the expression level. The data represent the mean \pm standard deviation of three biological replicates. Letters indicate significant differences between genotypes in each treatment by Tukey test $(\mathrm{p}<0,05)$.

repression on nitrate uptake mediated by HATS, or that $\mathrm{NO}_{3}$-HATS is unable to be regulated under these conditions to sustain efficient nitrate acquisition in coffee roots. The inhibitory effect of ammonium on $\mathrm{NO}_{3}$-HATS is a common feature previously shown in roots from several species, irrespective of plant N status (Minotti et al., 1969; Lee and Drew, 1986; Marschner et al., 1991; Orsel et al., 2006; Robinson et al., 2011). In contrast, the inability to regulate nitrate iHATS under $\mathrm{N}$ deficiency is unknown, despite the fact that iHATS were shown to be defective in Citrus roots under nitrate provision or decreased $\mathrm{NH}_{4} / \mathrm{NO}_{3}$

ratios (Camañes et al., 2009). In distinction to the regulation of the nitrate HATS, the LATS for ammonium and nitrate influx appeared to be insensitive to $\mathrm{N}$ status in coffee roots, as previously also shown for other higher plants (Siddiqi et al., 1990; Wang et al., 1993; Rawat et al., 1999; Cerezo et al., 2000), with exception for Arabidopsis (Okamoto et al., 2003). Considering that only a few physiological conditions have been investigated, the results presented here provide initial evidence for differential regulation of HATS activity for nitrate and ammonium in coffee roots and therefore, open questions and perspectives for further investigation. 

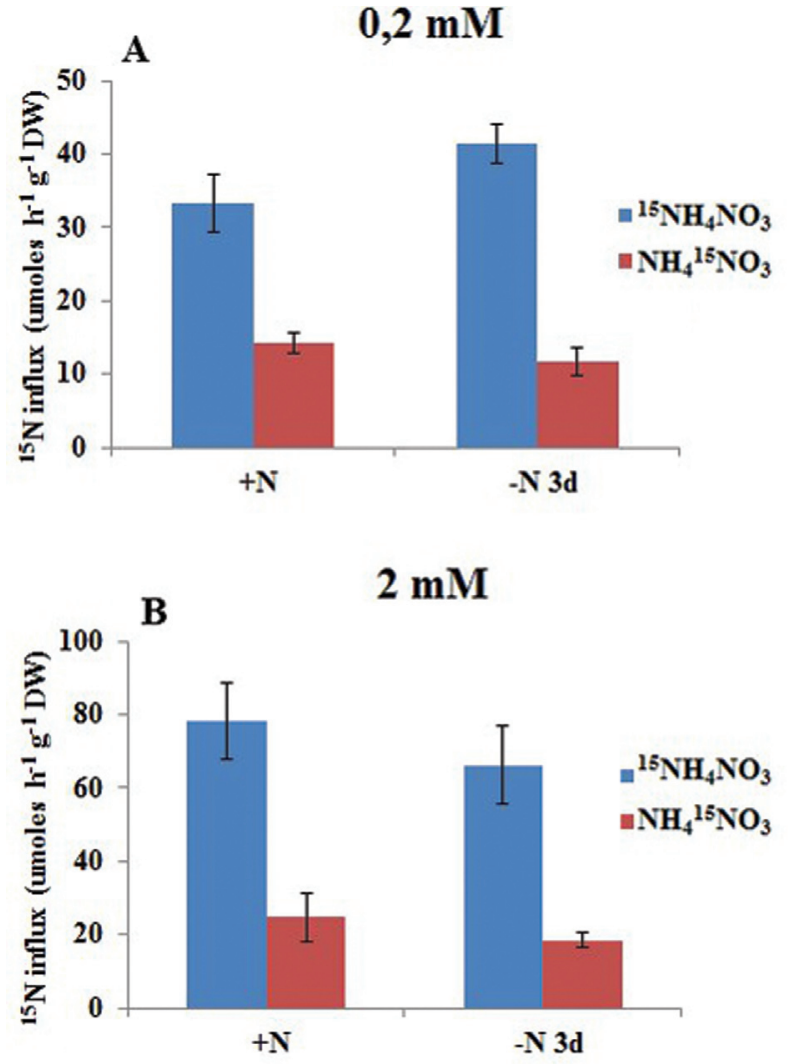

Figure 9 - HATS (A) and LATS (B) under N starvation in C. arabica roots, using ammonium nitrate labeled with ${ }^{15} \mathrm{~N}$. Details of the uptake experiment are described in Material and Methods.

Regardless of the mechanism responsible for this effect on nitrate uptake in coffee roots, our results show that when both inorganic $\mathrm{N}$ sources $\left(\mathrm{NH}_{4}{ }^{+}\right.$and $\left.\mathrm{NO}_{3}{ }^{-}\right)$are present in the nutrient solution, uptake of $\mathrm{NH}_{4}{ }^{+}$, mediated by either transport system (HATS or LATS), is favored compared to that of $\mathrm{NO}_{3}{ }^{-}$. This is commonly observed in several plant species and genera, including Citrus (Serna et al., 1992; Gessler et al., 1998; Gazzarrini et al., 1999; Min et al., 2000; Camañes et al., 2009), although, this situation results in greater availability of nitrate for leaching or denitrification, and further reduces the $\mathrm{N}$ use efficiency in coffee plants.

\section{Conclusions}

We presented in this study a genome-wide inventory of ammonium and nitrate transporter families in $C$. canephora, taking advantage of this recently released genome. We depicted transcriptional profile and phylogenetic patterns of $\mathrm{N}$ transporters in this tree species, and demonstrated that $C$. canephora genomic and transcriptional patterns follow the ones observed for most eudicots. Transcriptional analysis of selected transporters in C. arabica roots display distinct patterns, reinforcing that each member of the AMT and NRT families has a particular role in $\mathrm{N}$ uptake, which is influenced by $\mathrm{N}$ deprivation. $\mathrm{N}$-starvation demonstrated that ammonium uptake is favored over nitrate, in C. arabica roots. In summary, our study shows that, although nitrate transporters are prevalent compared to ammonium transporters in the Coffea genome, ammonium uptake is a preferential inorganic $\mathrm{N}$ source compared to nitrate. Additional approaches to dissect N-regulatory networks and molecular mechanisms underlying the spatial and temporal nature of the $\mathrm{N}$ transport response according to $\mathrm{N}$ demand for coffee plants are still necessary for detailed comprehension of $\mathrm{N}$ metabolism in coffee trees.

\section{Acknowledgments}

This work was funded by grants from "Consórcio Pesquisa Café", Fundação Araucária and CNPq. TBS, MSF and JDMS were recipients of CAPES fellowships. DSD is a CNPq research fellow.

\section{References}

Alber A, Ehlting B, Ehlting J, Hawkins BJ and Rennenberg $\mathrm{H}$

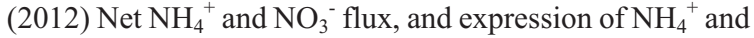
$\mathrm{NO}_{3}{ }^{-}$transporters in roots of Picea glauca. Trees 26:14031411.

Aslam M, Travis RL and Rains DW (1996) Evidence for substrate induction of a nitrate efflux system in barley roots. Plant Physiol 112:1167-1175.

Blum T, Briesemeister S and Kohlbacher O (2009) MultiLoc2: Integrating phylogeny and Gene Ontology terms improves subcellular protein localization prediction. BMC Bioinf 10:274.

Brandalise M, Severino FE, Maluf MP and Maia IG (2009) The promoter of a gene encoding an isoflavone reductase-like protein in coffee (Coffea arabica) drives a stress-responsive expression in leaves. Plant Cell Rep 28:1699.

Bu Y, Sun B, Zhou A, Zhang X, Lee I and Liu S (2013) Identification and characterization of a PutAMT1; 1 gene from Puccinellia tenuiflora. PloS One 8:e83111.

Camañes G, Cerezo M, Primo-Millo E, Gojon A and GarcíaAgustín P (2009) Ammonium transport and CitAMT1 expression are regulated by $\mathrm{N}$ in Citrus plants. Planta 229:331-342.

Cerezo M, Flors V, Legaz F an Garcya-Agustyn P (2000) Characterization of the low affinity transport system for $\mathrm{NO}_{3}{ }^{-}$uptake by Citrus roots. Plant Sci 160:95-104.

Chopin F, Wirth J, Dorbe MF, Lejay L, Krapp A, Gojon A and Daniel-Vedele F (2007) The Arabidopsis nitrate transporter AtNRT2.1 is targeted to the root plasma membrane. Plant Physiol Biochem 45:630-635.

Couturier J, Montanini B, Martin F, Brun A, Blaudez D and Chalot M (2007) The expanded family of ammonium transporters in the perennial poplar plant. New Phytol 174:137150.

Crawford NM and Glass AD (1998) Molecular and physiological aspects of nitrate uptake in plants. Trends Plant Sci 3:389395.

Davis AP, Tosh J, Ruch N and Fay MF (2011) Growing coffee: Psilanthus (Rubiaceae) subsumed on the basis of molecular and morphological data; implications for the size, morphol- 
ogy, distribution and evolutionary history of Coffea. Bot J Linn Soc 167:357-377.

de Carvalho K, Bespalhok Filho JC, dos Santos TB, de Souza SGH, Vieira LGE, Pereira LFP and Domingues DS (2013) Nitrogen starvation, salt and heat stress in coffee (Coffea arabica L.): Identification and validation of new genes for qPCR normalization. Mol Biotechnol 53:315-325.

Dechorgnat J, Nguyen CT, Armengaud P, Jossier M, Diatloff E, Filleur S and Daniel-Vedele F (2011) From the soil to the seeds: The long journey of nitrate in plants. J Exp Bot 62:1349-1359.

Dereeper A, Bocs S, Rouard M, Guignon V, Ravel S, TranchantDubreuil C, Poncet V, Garsmeur O, Lashmeres P and Droc G (2015) The coffee genome hub: A resource for coffee genomes. Nucleic Acids Res 43:D1028-D1035.

Denoeud F, Carretero-Paulet L, Dereeper A, Droc G, Guyot R, Pietrella M, Zheng C, Alberti A, Anthony F, Aprea G, et al. (2014) The coffee genome provides insight into the convergent evolution of caffeine biosynthesis. Science 345:11811184.

dos Santos TB, Budzinski IG, Marur CJ, Petkowicz CL, Pereira LF and Vieira LG (2011) Expression of three galactinol synthase isoforms in Coffea arabica L. and accumulation of raffinose and stachyose in response to abiotic stresses. Plant Physiol Biochem 49:441-448.

dos Santos TB, Lima RB, Nagashima GT, Petkowicz CLO, Carpentieri-Pípolo V, Pereira LFP, Domingues DS and Vieira LGE (2015) Galactinol synthase transcriptional profile in two genotypes of Coffea canephora with contrasting tolerance to drought. Genet Mol Biol 38:182-190.

Edgar RC (2004) MUSCLE: Multiple sequence alignment with high accuracy and high throughput. Nucleic Acids Res 32:1792-1797.

Fan SC, Lin CS, Hsu PK, Lin SH and Tsay YF (2009) The Arabidopsis nitrate transporter NRT1.7, expressed in phloem, is responsible for source-to-sink remobilization of nitrate. Plant Cell 21:2750-2761.

Fehr LCF de A, Duarte SL, Tavares M and Reis EA (2012) Análise temporal das variáveis de custos da cultura do café arábica nas principais regiões produtoras do Brasil. Custos e @ gronegócio on line 8:161-187.

Ferreira DF (2011) Sisvar: A computer statistical analysis system. Ciênc Agrotecnol 35:1039-1042.

Forde BG (2000) Nitrate transporters in plants: Structure, function and regulation. Biochim Biophys Acta 1465:219-236.

Freschi L, Nievola CC, Rodrigues MA, Domingues DS, Sluys MAV and Mercier H (2009) Thermoperiod affects the diurnal cycle of nitrate reductase expression and activity in pineapple plants by modulating the endogenous levels of cytokinins. Physiol Plantarum 137:201-212.

Gazzarrini S, Lejay L, Gojon A, Ninnemann O and Frommer WB (1999) Three functional transporters for constitutive, diurnally regulated and starvation-induced uptake of ammonium into Arabidopsis roots. Plant Cell 11:937-947.

Gessler A, Schneider S, Weber P, Hanemann U and Rennenberg $\mathrm{H}$ (1998) Soluble N compounds in trees exposed to high loads of N: A comparison between the roots of Norway spruce (Picea abies) and beech (Fagus sylvatica) trees grown under field conditions. New Phytol 138:385-399.

Graff L, Obrdlik P, Yuan L, Loqué D, Frommer WB and von Wirén N (2011) N-terminal cysteines affect oligomer stabil- ity of the allosterically regulated ammonium transporter LeAMT1; 1. J Exp Bot 62:1361-1373.

Guether M, Neuhauser B, Balestrini R, Dynowski M, Ludewig U and Bonfante P (2009) A mycorrhizal-specific ammonium transporter from Lotus japonicus acquires nitrogen released by arbuscular mycorrhizal fungi. Plant Physiol 150:73-83.

Kanno Y, Hanada A, Chiba Y, Ichikawa T, Nakazawa M, Matsui M, Koshiba T, Kamiya Y and Seo M (2012) Identification of an abscisic acid transporter by functional screening using the receptor complex as a sensor. Proc Natl Acad Sci U S A 109:9653-9658.

Koegel S, Ait Lahmidi N, Arnould C, Chatagnier O, Walder F, Ineichen $\mathrm{K}$, Boller T, Wipf D, Wiemken A and Courty PE (2013) The family of ammonium transporters (AMT) in Sorghum bicolor: Two AMT members are induced locally, but not systemically in roots colonized by arbuscular mycorrhizal fungi. New Phytol 198:853-865.

Konishi M and Yanagisawa S (2014) Emergence of a new step towards understanding the molecular mechanisms underlying nitrate-regulated gene expression. J Exp Bot 65:5589-5600.

Kronzucker HJ, Siddiqi MY and Glass AD (1997) Conifer root discrimination against soil nitrate and the ecology of forest succession. Nature 385:59-61.

Kronzucker HJ, Schjoering JK, Erner Y, Kirk GJD, Siddiqi MY and Glass ADM (1998) Dynamic interactions between root $\mathrm{NH}_{4}{ }^{+}$influx and long-distance $\mathrm{N}$ translocation in rice: Insights into feedback processes. Plant Cell Physiol 39:12871293.

Kronzucker HJ, Siddiqi MY, Glass AD and Kirk GJ (1999) Nitrate-ammonium synergism in rice. A subcellular flux analysis. Plant Physiol 119:1041-1046.

Krogh A, Larsson B, Von Heijne G and Sonnhammer EL (2001) Predicting transmembrane protein topology with a hidden Markov model: Application to complete genomes. J Mol Biol 305:567-580.

Lanquar V, Loqué D, Hörmann F, Yuan L, Bohner A, Engelsberger WR, Lalonde S, Schulze WX, von Wirén N and Frommer WB (2009) Feedback inhibition of ammonium uptake by a phospho-dependent allosteric mechanism in Arabidopsis. Plant Cell 21:3610-3622.

Lashermes P, Andrade AC and Etienne H (2008) Genomics of coffee, one of the world's largest traded commodities. In: Moore H and Ming R (eds) Genomics of Tropical Crop Plants. Springer, Berlin, pp 203-226.

Lee RB and Drew MC (1986) Nitrogen-13 studies of nitrate fluxes in barley roots II. Effect of plant N-status on the kinetic parameters of nitrate influx. J Exp Bot 37:1768-1779.

Léran S, Varala K, Boyer JC, Chiurazzi M, Crawford N, Daniel-Vedele F, David L, Dickstein R, Fernandez E, Forde B, et al. (2014) A unified nomenclature of Nitrate Transporter 1/Peptide Transporter family members in plants. Trends Plant Sci 19:5-9.

Li W, Wang Y, Okamoto M, Crawford NM, Siddiqi MY and Glass AD (2007) Dissection of the AtNRT2.1: AtNRT2.2 inducible high-affinity nitrate transporter gene cluster. Plant Physiol 143:425-433.

Liu KH and Tsay YF (2003) Switching between the two action modes of the dual-affinity nitrate transporter CHL1 by phosphorylation. EMBO J 22:1005-1013.

Loqué D and von Wirén N (2004) Regulatory levels for the transport of ammonium in plant roots. J Exp Bot 55:1293-1305. 
Loqué D, Yuan L, Kojima S, Gojon A, Wirth J, Gazzarrini S, Ishiyama, Takahashi $\mathrm{H}$ and von Wirén, N (2006) Additive contribution of $A M T 1 ; 1$ and $A M T 1 ; 3$ to high-affinity ammonium uptake across the plasma membrane of nitrogendeficient Arabidopsis roots. Plant J 48:522-534.

Loqué D, Lalonde S, Looger LL, von Wirén N and Frommer WB (2007) A cytosolic trans-activation domain essential for ammonium uptake. Nature 446:195-198.

Ludewig U, Neuhäuser B and Dynowski M (2007) Molecular mechanisms of ammonium transport and accumulation in plants. FEBS Lett 581:2301-2308.

Luo J, Qin J, He F, Li H, Liu T, Polle A, Peng C and Luo ZB (2013) Net fluxes of ammonium and nitrate in association with $\mathrm{H}^{+}$fluxes in fine roots of Populus popularis. Planta 237:919-931.

Marschner H, Häussling M and George E (1991) Ammonium and nitrate uptake rates and rhizosphere $\mathrm{pH}$ in non-mycorrhizal roots of Norway spruce [Picea abies (L.) Karst.]. Trees 5:14-21.

Marschner H (2012) Marschner's Mineral Nutrition of Higher Plants (Vol. 89). Academic Press, London, 672 p.

McDonald TR, Dietrich FS and Lutzoni F (2012) Multiple horizontal gene transfers of ammonium transporters/ammonia permeases from prokaryotes to eukaryotes: Toward a new functional and evolutionary classification. Mol Biol Evol 29:51-60

Migocka M, Warzybok A and Klobus G (2013) The genomic organization and transcriptional pattern of genes encoding nitrate transporters 1 (NRT1) in cucumber. Plant Soil 364:245-260.

Min X, Siddiqi MY, Guy RD, Glass AD and Kronzucker HJ (2000) A comparative kinetic analysis of nitrate and ammonium influx in two early-successional tree species of temperate and boreal forest ecosystems. Plant Cell Environ 23:321-328.

Minotti PL, Williams DC and Jackson WA (1969) Nitrate uptake by wheat as influenced by ammonium and other cations. Crop Sci 9:9-14.

Mondego JM, Vidal RO, Carazzolle MF, Tokuda EK, Parizzi LP, Costa GG, Pereira LF, Andrade AC, Colombo CA, Vieira LGE, et al. (2011) An EST-based analysis identifies new genes and reveals distinctive gene expression features of Coffea arabica and Coffea canephora. BMC Plant Biol 11:30.

Näsholm T, Ekblad A, Nordin A, Giesler R, Högberg M and Högberg P (1998) Boreal forest plants take up organic nitrogen. Nature 392:914-916.

Nazoa P, Vidmar JJ, Tranbarger TJ, Mouline K, Damiani I, Tillard P, Glass AD and Touraine B (2003) Regulation of the nitrate transporter gene AtNRT2.1 in Arabidopsis thaliana: Responses to nitrate, amino acids and developmental stage. Plant Mol Biol 52:689-703.

Neuhäuser B, Dynowski M and Ludewig U (2009) Channel-like $\mathrm{NH}_{3}$ flux by ammonium transporter AtAMT2. FEBS Lett 583:2833-2838.

Nour-Eldin HH, Andersen TG, Burow M, Madsen SR, Jørgensen ME, Olsen CE, Dreyer I, Hedrich R, Geiger D and Halkier BA (2012) NRT/PTR transporters are essential for translocation of glucosinolate defence compounds to seeds. Nature 488:531-534.
Okamoto M, Vidmar JJ and Glass AD (2003) Regulation of NRT1 and NRT2 gene families of Arabidopsis thaliana: Responses to nitrate provision. Plant Cell Physiol 44:304-317.

Orsel M, Chopin F, Leleu O, Smith SJ, Krapp A, Daniel-Vedele F and Miller AJ (2006) Characterization of a two-component high-affinity nitrate uptake system in Arabidopsis. Physiology and protein-protein interaction. Plant Physiol 142:1304-1317.

Patterson K, Cakmak T, Cooper A, Lager I, Rasmusson AG and Escobar MA (2010) Distinct signalling pathways and transcriptome response signatures differentiate ammonium- and nitrate-supplied plants. Plant Cell Environ 33:1486-1501.

Pellizzaro A, Clochard T, Planchet E, Limami AM and Paven ML (2014) Identification and molecular characterization of Medicago truncatula NRT2 and NAR2 families. Physiol Plantarum 154:256-269.

Pii Y, Alessandrini M, Guardini K, Zamboni A and Varanini Z (2014) Induction of high-affinity NO3-uptake in grapevine roots is an active process correlated to the expression of specific members of the NRT2 and plasma membrane H+-ATPase gene families. Funct Plant Biol 41:353-365.

Rawat SR, Silim SN, Kronzucker HJ, Siddiqi MY and Glass AD (1999) AtAMT1 gene expression and $\mathrm{NH}_{4}{ }^{+}$uptake in roots of Arabidopsis thaliana: Evidence for regulation by root glutamine levels. Plant J 19:143-152.

Robinson N, Brackin R, Vinall K, Soper F, Holst J, Gamage H, Paungfoo-Lonhienne C, Rennenberg H, Lakshmanan P and Schmidt S (2011) Nitrate paradigm does not hold up for sugarcane. PLoS One 6:e19045.

Saitou N and Nei M (1987) The neighbor-joining method: A new method for reconstructing phylogenetic trees. Mol Biol Evol 4:406-425.

Serna MD, Borras R, Legaz F and Primo-Millo E (1992) The influence of nitrogen concentration and ammonium/nitrate ratio on $\mathrm{N}$-uptake, mineral composition and yield of citrus. Plant Soil 147:13-23.

Siddiqi MY, Glass ADM, Ruth TJ and Fernando M (1989) Studies of the regulation of nitrate influx by barley seedlings using ${ }^{13} \mathrm{NO}_{3}^{-}$. Plant Physiol 90:806-813.

Siddiqi MY, Glass ADM, Ruth TJ and Rufty TW (1990) Studies of the uptake of nitrate in barley. I: Kinetics of ${ }^{13} \mathrm{NO}_{3}{ }^{-}$influx. Plant Physiol 93:1426- 1432.

Sorgona A, Lupini A, Mercati F, Di Dio L, Sunseri F and Abenavoli MR (2011) Nitrate uptake along the maize primary root: An integrated physiological and molecular approach. Plant Cell Environ 34:1127-1140.

Tamura K, Stecher G, Peterson D, Filipski A and Kumar S (2013) MEGA6: Molecular Evolutionary Genetics Analysis version 6.0. Mol Biol Evol 30:2725-2729.

Tischner R (2000) Nitrate uptake and reduction in higher and lower plants. Plant Cell Environ 23:1005-1024.

Vidal RO, Mondego JMC, Pot D, Ambrósio AB, Andrade AC, Pereira LFP, Colombo CA, Vieira LGE, Carazzolle MF and Pereira, GAG (2010) A high-throughput data mining of single nucleotide polymorphisms in Coffea species expressed sequence tags suggests differential homeologous gene expression in the allotetraploid Coffea arabica. Plant Physiol 154:1053-1066.

von Wirén N, Gazzarrini S, Gojont A and Frommer WB (2000) The molecular physiology of ammonium uptake and retrieval. Curr Opin Plant Biol 3:254-261. 
von Wittgenstein NJ, Le CH, Hawkins BJ and Ehlting J (2014) Evolutionary classification of ammonium, nitrate, and peptide transporters in land plants. BMC Evol Biol 14:11.

Wang MY, Siddiqi MY, Ruth TJ and Glass ADM (1993) Ammonium uptake by rice roots. II. Kinetics of ${ }^{13} \mathrm{NH}_{4}{ }^{+}$influx across the plasmalemma. Plant Physiol 103:1259-1267.

Wang H, Ahan J, Wu Z, Shi D, Liu B and Yang C (2012) Alteration of nitrogen metabolism in rice variety 'Nipponbare' induced by alkali stress. Plant Soil 355:131-147.

Wang YY, Hsu PK and Tsay YF (2012) Uptake, allocation and signaling of nitrate. Trends Plant Sci 17:458-467.

Xu G, Fan X and Miller AJ (2012) Plant nitrogen assimilation and use efficiency. Annu Rev Plant Biol 63:153-182.

Young ND, Debellé F, Oldroyd GE, Geurts R, Cannon SB, Udvardi MK, Benedito VA, Mayer KFX, Gouzy J, Schoof $\mathrm{H}$, et al. (2011) The Medicago genome provides insight into the evolution of rhizobial symbioses. Nature 480:520-524.

Yuan L, Loqué D, Ye F, Frommer WB and von Wirén N (2007) Nitrogen-dependent post transcriptional regulation of the ammonium transporter AtAMT1;1. Plant Physiol 143:732744.

Yuan L, Graff L, Loqué D, Kojima S, Tsuchiya YN, Takahashi H and von Wirén N (2009) AtAMT1;4, a pollen-specific high-affinity ammonium transporter of the plasma membrane in Arabidopsis. Plant Cell Physiol 50:13-25.
Zhuo D, Okamoto M, Vidmar JJ and Glass AD (1999) Regulation of a putative high-affinity nitrate transporter $(\mathrm{Nrt} 2 ; 1 \mathrm{At})$ in roots of Arabidopsis thaliana. Plant J 17:563-568.

\section{Supplementary material}

The following online material is available for this article:

Figure S1 - N starvation experiment

Figure S2 - Neighbor joining phylogenetic analysis of the NRT1/PTR family.

Figure S3 - Semi-quantitative RT-PCR analysis of CaAMTs and CaNRTs.

Table S1 - Coffea canephora AMT1 gene family overall features.

Table S2 - Coffea canephora AMT2 gene family overall features.

Table S3 - Coffea canephora NRT1 gene family overall features.

Table S4 - Coffea canephora NRT2 gene family overall features.

Associate Editor: Marcio de Castro Silva Filho

License information: This is an open-access article distributed under the terms of the Creative Commons Attribution License (type CC-BY), which permits unrestricted use, distribution and reproduction in any medium, provided the original article is properly cited. 